Research/Technical Note

\title{
Anaerobic and Aerobic Growth of Bacillus Licheniformis in Gasoline Contaminated Soil of Federal Institute of Industrial Research Oshodi (Fiiro), Lagos, Nigeria
}

\author{
Omotere Igbahan Odola ${ }^{1,}$, Chiedu Owabor ${ }^{1}$, Motunrayo Nofiat Odola ${ }^{2}$ \\ ${ }^{1}$ Department of Chemical Engineering, University of Benin (UNIBEN), Benin City, Nigeria \\ ${ }^{2}$ Department of Biology Education, University of Benin (UNIBEN), Benin City, Nigeria \\ Email Address: \\ odola_godwin@yahoo.com(O. I. Odola),owabor4you@yahoo.com(C. Owabor),nofiatmoturayo@gmail.com (M. N. Odola) \\ ${ }^{*}$ Corresponding author
}

\section{To cite this article:}

Omotere Igbahan Odola, Chiedu Owabor, Motunrayo Nofiat Odola. Anaerobic and Aerobic Growth of Bacillus Licheniformis in Gasoline Contaminated Soil of Federal Institute of Industrial Research Oshodi (Fiiro), Lagos, Nigeria. International Journal of Atmospheric and Oceanic Sciences. Vol. 3, No. 1, 2019, pp. 8-12. doi: 10.11648/j.ijaos.20190301.12

Received: November 25, 2018; Accepted: January 14, 2019; Published: January 31, 2019

\begin{abstract}
Studies on the anaerobic and aerobic growth of Bacillus licheniformis bacteria show that the same growth factor suffice for both aerobic and anaerobic growth, thus supporting $[13,22]$ formulation of photosynthesis and carbon assimilation in these forms, and his thesis that the previously observed need for peptone or yeast extract could be attributed to their content of essential growth factors. A bottle technique for anaerobic cultures and a flask technique for aerobic cultures are described in detail. Photosynthesis in Bacillus licheniformis bacteria is best observed when they are grown anaerobic. The experiments described here indicate that although the culture media had to be modified to conform to certain special requirement imposed by anaerobic growth, the required growth factors remained the same. The Bacillus licheniformis bacteria display the same growth pattern in both aerobic and anaerobic condition in ethylene substrate but there was slight change of its growth pattern in both aerobic and anaerobic condition for xylene and benzene substrate which are aromatic compounds. This study shows higher growth of Bacillus licheniformis bacteria in aerobic condition than anaerobic condition. The Bacillus licheniformis bacteria had the highest bacterial population of $1.66 \times 10^{7} \mathrm{CFU} / \mathrm{g}$ in ethylene substrate for week four in this experiment. The findings suggest that Bacillus licheniformis bacteria is most adapted to conditions present in soils contaminated with gasoline and hence can be exploited in bioremediation activities [18].
\end{abstract}

Keywords: Bacillus Licheniformis, Growth Factors, Growth Pattern, Hydrocarbon, Utilization

\section{Introduction}

Utilization of bacterial strains specifically from genus Bacillus is gaining momentum because of their ability to resist and survive under harsh industrial conditions. Bacillus licheniformis, Bacillus subtilis and Bacillus pumilus are some of the strains that are associated with food spoilage and with a wide range of different clinical conditions [12]. B. licheniformis has proved itself as a multipurpose organism and has gained popularity along with B. subtilis. B. licheniformis is a saprophytic bacterium commonly found in soil, as well as on the feathers of ground dwelling birds and other natural environments. The cells are capable of degrading several substrates and growing on a large diversity of nutrient sources due to its capacity of producing and secreting plenty of hydrolytic enzymes [5].

Contamination of soil environment by hydrocarbons (mostly petroleum hydrocarbons) is becoming prevalent across the globe. The amount of natural crude oil seepage is estimated to be 600,000 metric tons per year with a range of uncertainty of 200,000 metric tons per year [16]. Release of hydrocarbons into the environment whether accidentally or due to human activities is a main cause of water and soil pollution. These hydrocarbon pollutants usually cause disruptions of natural equilibrium between the living species 
and their natural environment. Hydrocarbon components have been known to belong to the family of carcinogens and neurotoxic organic pollutants $[7,9]$. The toxicity of crude oil or petroleum products varies widely, depending on their composition and concentration, on environmental factors and on the biological state of the organisms at the time of the contamination in heavily polluted areas, there are immediate detrimental effects on plant and animal lives, including agriculture $[3,10]$.

Animals and plants may be affected by the physical properties of floating oil which prevent respiration, photosynthesis or feeding. Many water soluble components of crude oil and refined products are toxic to marine organisms. In addition to killing such organisms, oil spillage appears to have more subtle effects by disrupting the chemoreception of such organisms leading to elimination of many species from the spilled area even when the oil concentration is far below the lethal level, since feeding and mating responses largely depend on chemoreception. More so, contaminated land sites are health hazards for human beings and thus, are unsuitable for housing or agriculture. The downward migration of crude oil pollutants from the soil into the groundwater is especially problematic in developing countries where groundwater is often directly used for drinking without any prior treatment. Aromatic hydrocarbons are common environmental pollutants with toxic, genotoxic, mutagenic and carcinogenic properties $[11,14]$. They mainly occur in petroleum industry activities. Oil spills because of pipeline breakages, tanks leakages or storage and transportation accidents can be considered as the most frequent causes of hydrocarbon release, included PAHs into soils. BTEX compounds are components of gasoline and aviation fuels that are carcinogenic and neurotoxic to most organisms [15, 20].

Bacteria play a major role in hydrocarbon degradation. The reason for petroleum biodegradation is the ability of microorganisms to utilize hydrocarbons to satisfy their cell growth and energy needs. Low molecular weight alkanes are degraded most rapidly whereas mixed cultures carry out more extensive biodegradation of petroleum through pure cultures. Therefore, biodegradation using microorganisms is usually preferred. They play major role in PAHs removal from contaminated environments because of some advantages such as cost effectiveness and more complete cleanup [1]. Sixteen bacteria capable of utilizing gasoline as their sole source of carbon and energy for growth from Federal Institute of Industrial Research Oshodi (FIIRO) soils in Lagos, Nigeria were isolated and characterized. The usage of petroleum hydrocarbon products has been increased. Therefore, the soil contamination with gasoline is becoming one of the major environmental problems. Various microbial species are effective degraders of hydrocarbons in natural environment. Microorganisms such as bacteria, fungi, yeast and microalgae can degrade petroleum hydrocarbons [2, 21].

In this study we determine the anaerobic and aerobic growth of Bacillus lichenformis bacteria indigenous to gasoline contaminated soil.

The objectives were; (a). To isolate and identify bacteria associated with utilization of gasoline.

(b). To characterize the bacteria.

(c). To determine the Bacillus lichenformis plate counts bacteria population in xylene, benzene and ethylene substrate.

\section{Materials and Methods}

The sandy soil used in this experiment was obtained from Federal Institute of Industrial Research Oshodi (FIIRO), Lagos State, Nigeria. $1 \mathrm{~kg}$ of soil sample was collected from two different spots in Federal Institute of Industrial Research Oshodi (FIIRO), Lagos State of Nigeria. Soil was sampled with the sampler Auger of $0-15 \mathrm{~cm}$ depth. The sample was scrapped into sterile plastic bag and maintained in aseptic conditions. The sample was taken to (FIIRO) Biotechnology laboratory for analysis. On collection, stones and refuse were separated from the soil sample. Further separation was carried out using $2 \mathrm{~mm}$ mesh size to remove the larger non-sandy fractions from the sandy. 500gram of soil sample was spiked with $100 \mathrm{ML}$ of gasoline in ratio 5:1, evenly mixed with spatula and spread on a woody rack to dry for two days and it was sieved with a $2 \mathrm{~mm}$ sieve in other to remove various sizes of stones and refuse [6]

Isolation of soil hydrocarbon degrading bacteria was performed by serial dilution method .1 gram of soil sample was weighed into a MCarthney (sample bottle) bottle and dissolved with $10 \mathrm{ml}$ distilled water. 1 gram of soil sample was then serially diluted in sterilized distilled water to get a concentration range from $10^{-1}$ to $10^{-6}$.

$150 \mathrm{ML}$ of Minimal salt medium was put into $250 \mathrm{ML}$ conical flask and inoculated with 1 gram of the soil sample. Gasoline was sterilized separately before it was added to the medium at $1.0 \%(\mathrm{v} / \mathrm{v})$. A volume of $0.1 \mathrm{ml}$ of each dilution was transferred aseptically to MSA plates (Petri dish). The sample was spread uniformly. The culture was incubated with shaking at $120 \mathrm{rev} / \mathrm{min}$ and was incubated at $30^{\circ} \mathrm{C}$ for $7-12$ days. The bacteria isolates was further sub cultured to obtain pure culture. Pure isolates on nutrient agar slants was then maintained at $4^{\circ} \mathrm{C}$ in a refrigerator to avoid overgrowth [19].

The gasoline was purchased from Mobil Oil filling station in Oshodi, Lagos. The distilled water used for dissolving the soil, washing apparatus was obtained in Federal Institute of Industrial Research Oshodi (FIIRO), Lagos, Nigeria.

Hydrogen peroxide $\left(\mathrm{H}_{2} \mathrm{O}_{2}\right) 3 \%(\mathrm{~W} / \mathrm{v})$, a product of Sigma Aldrich, USA, Kovac's reagents, a product of Sigma Aldrich, USA, and gram staining reagents, a product of Sigma Aldrich, USA, were bought from Rochester Silicate Limited chemical store in Mushin, Lagos, Nigeria for biochemical characterization of bacterial isolates [13, 22].

Some of the sterile nutrient agar plates were exposed to air for 30 minutes in order to isolate microbial cultures from environment. The above mentioned procedure for isolation was followed. All morphologically contrasting colonies were purified by repeated streaking. Identification of the genus was based on morphological and biochemical characteristics for 
Bacillus species. All the tests were performed on liquid cultures in late-logarithmic phase.

The methanol solvent manufactured by Sigma Aldrich, USA, was used for extraction of gasoline from soil was bought from a chemical store in Lagos, Nigeria. The Nutrient Agar a product of Himedia laboratories pvt Ltd, used for supporting the growth of bacterial was purchased from Richmond Consultants store, Mushin, Lagos, Nigeria [18]. The Bacillus lichenformis bacteria was isolated and selected from the mixed cultured, purified and enriched in MSA medium which consist of $\mathrm{Mg}_{2} \mathrm{SO}_{4} .7 \mathrm{H}_{2} \mathrm{O} \quad 0.05 \mathrm{~g} / \mathrm{ML}, \mathrm{Na}_{2} \mathrm{HPO}_{4} \quad 1.0 \mathrm{~g} / \mathrm{ML}$, $\mathrm{KH}_{2} \mathrm{PO}_{4} \quad 0.265 / \mathrm{ML}, \mathrm{NH}_{4} \mathrm{NO}_{3} 2.0 \mathrm{~g} / \mathrm{ML}, \mathrm{K}_{2} \mathrm{HPO}_{4} 0.1 \mathrm{~g} / \mathrm{ML}$, Agar $7.5 \mathrm{~g} / \mathrm{ML}$, substrate $2 \%$ dissolved in $500 \mathrm{ML}_{2} \mathrm{O}$.

\subsection{Anaerobic}

The culture vessels were '250 ML.' Pyrex bottles with interchangeable stoppers. The 10 conical flasks of $250 \mathrm{ML}$ (bioreactors) at room temperature. The air tightened bioreactors were designated $\mathrm{N}_{1}-\mathrm{N}_{10}$ (anaerobic). 15 gram of gasoline spiked soil were weighed into each of the bioreactor in a solution of Minimal Salt Medium (MSM) $150 \mathrm{ML}$ and mixed properly at room temperature $30^{\circ} \mathrm{C} \pm 3{ }^{\circ} \mathrm{C}$ and Autoclave at $121^{\circ} \mathrm{C}$ for 15 minutes. The bioreactor $\mathrm{N}_{2}-\mathrm{N}_{10}$ (anaerobic) were amended with $3 \mathrm{ML}$ substrate, benzene $\mathrm{N}_{2}-\mathrm{N}_{4}$; xylene $\mathrm{N}_{5}-\mathrm{N}_{7}$ and ethylene $\mathrm{N}_{8}-\mathrm{N}_{10}$ respectively after cooling and pure culture of Bacillus lichenformis bacteria. The bioreactor under treatment $\mathrm{N}_{1}$ (control) was not amended with any biostimulating agent and microbes. In total, 10 microcosms were settled and incubated for 42 days. All bioreactors were mixed manually once per week to enhance oxygenation and kept moist during the 42 days experimental duration. The set-up was monitored under anaerobic condition. Samples were withdrawn at intervals of one week for microbial population analysis respectively $[3,18]$.

\subsection{Aerobic}

The culture vessels were '250 ML.' Pyrex bottles with interchangeable stoppers. There were 10 conical flasks of $250 \mathrm{ML}$ (bioreactors) at room temperature. The bioreactors slightly closed were designated $\mathrm{D}_{1}-\mathrm{D}_{10}$ (aerobic). 15 gram of gasoline spiked soil were weighed into each of the bioreactor in a solution of Minimal Salt Medium (MSM) $150 \mathrm{ML}$ and mixed properly at room temperature $30^{\circ} \mathrm{C} \pm$ $3^{\circ} \mathrm{C}$ and Autoclave at $121^{\circ} \mathrm{C}$ for 15 minutes. The bioreactor $\mathrm{D}_{2}-\mathrm{D}_{10}$ (aerobic) were amended with 3 ML substrate , benzene $D_{2}-D_{4} ;$ xylene $D_{5}-D_{7}$ and ethylene $D_{8}-D_{10}$ respectively after cooling and pure culture of Bacillus lichenformis bacteria. The bioreactor under treatment $\mathrm{D}_{1}$ (control) was not amended with any biostimulating agent and microbes. In total, 10 microcosms were settled and incubated for 42 days. All bioreactors were mixed manually once per week to enhance oxygenation and kept moist during the 42 days experimental duration. The set-up was monitored under aerobic condition. Samples were withdrawn at intervals of one week for microbial population analysis respectively $[3,18]$.

\section{Results and Discussion}

Among several organisms, bacteria have now become the choice of selection for various industrial processes. One of the main reasons is that they can be genetically modified to produce the desired activity and minimize the undesired products. Screening of a large number of microorganisms is an important step in selecting a highly potent microbial culture for multipurpose utilization. Many studies have been conducted previously in order to search and select new bacterial isolates that can substitute fungi by bacterial isolates for the production of various enzymes at industrial scale. Current study is an attempt to isolate potent bacterial culture especially $B$. licheniformisthat has the capability of producing multiple enzymes.

Most micro organisms grow on bio film which provides a protective environment for the micro colonies of bacteria attached to the particle surface.

The growth pattern of microorganism can generally be described in four phases: the lag phase, exponential or growth phase, stationary phase, declining growth or death phase. The microbial population is measured in terms of number of viable micro organisms [17]. It should be noted that in any specific population, not all cells are in the same phase of the growth curve at any time. Some cells may be in the growth phase while others are in death phase. Different microorganism do not all have identical growth curves, each species has its own specific growth curve. The growth curve for species will not be identical for different environmental conditions.

The bacterial plate counts of Bacillus lichenformis in the soil samples collected from FIIRO compound are presented in Figure 1 and figure 2.

Figure 1. show that Bacillus licheniformis plate counts of bacterial population in ethylene substrate show lag phase from week zero to one, exponential phase from week one to two, decline phase from week two to three, exponential phase from week three to four, stationary phase from week four to five and decline phase from week five to six. The Bacillus licheniformis plate counts of bacterial population in benzene substrate show lag phase from week zero to one, exponential phase from week one to four, stationary phase from week four to five and decline phase from week five to six. The Bacillus licheniformis plate counts of bacterial population in xylene substrate show lag phase from week zero to one, stationary phase from week one to two, exponential phase from week two to four, stationary phase from week four to five and decline phase from week five to six. The Bacillus licheniformis bacteria had the highest bacterial population of $1.66 \times 10^{7} \mathrm{CFU} / \mathrm{g}$ in ethylene substrate for week four [18]. 


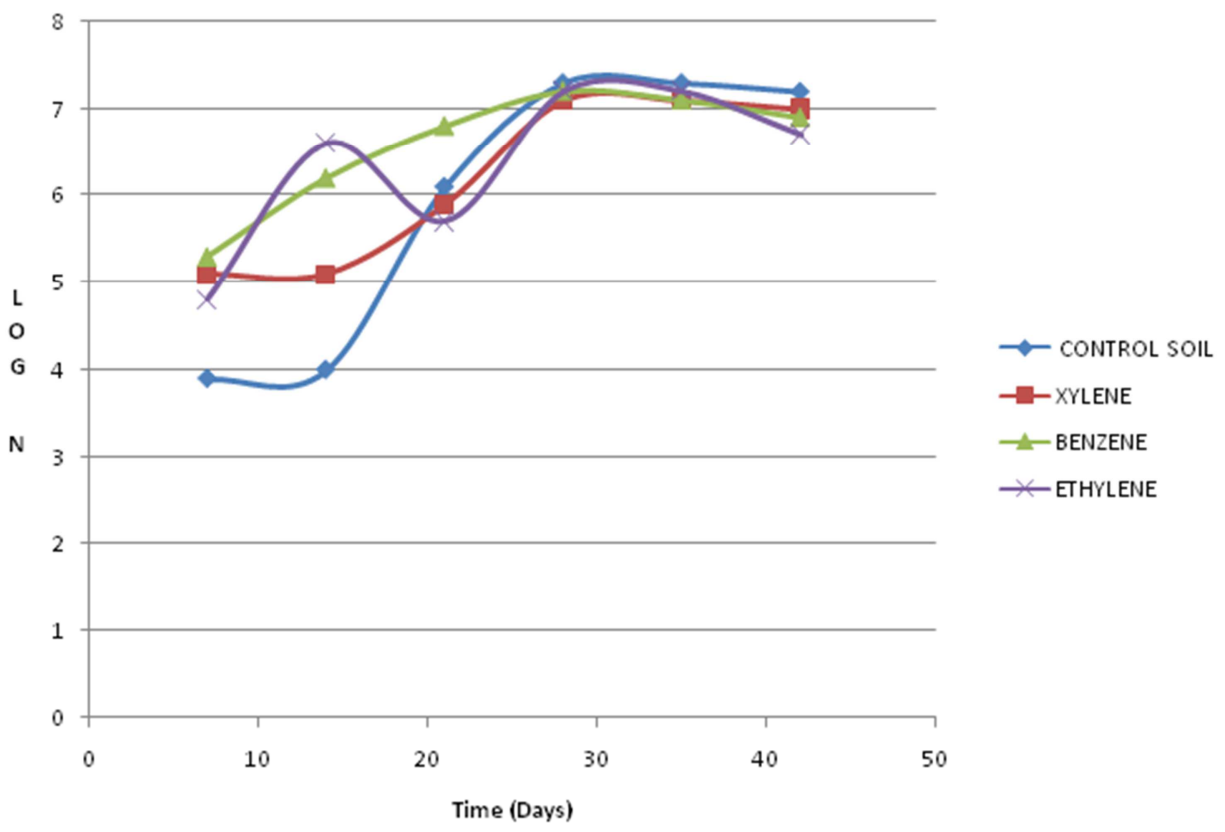

Figure 1. variation of LOG $N$ with time, for Bacillus licheniformis (Aerobic).

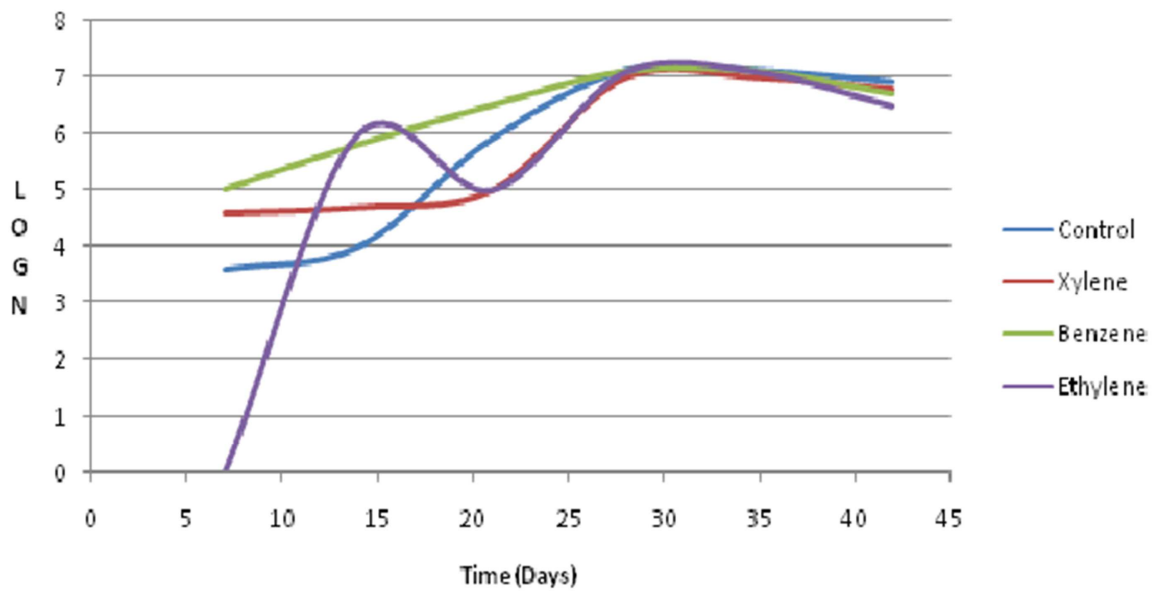

Figure 2. variation of $L O G N$ with time, for Bacillus licheniformis (Anaerobic).

Figure 2. show that Bacillus licheniformis plate counts of bacterial population in ethylene substrate show lag phase from week zero to one, exponential phase from week one to two, decline phase from week two to three, exponential phase from week three to four, stationary phase from week four to five and decline phase from week five to six. The Bacillus licheniformis plate counts of bacterial population in benzene substrate show lag phase from week zero to one, linear from week one to four, stationary phase from week four to five and decline phase from week five to six. The Bacillus licheniformis plate counts of bacterial population in xylene substrate show lag phase from week zero to one, stationary phase from week one to three, exponential phase from week three to four, stationary phase from week four to five and decline phase from week five to six. The Bacillus licheniformis bacteria had the highest bacterial population of $1.35 \times 10^{7} \mathrm{CFU} / \mathrm{g}$ in ethylene substrate for week four [18].

Soils are considered viable with plate counts of $10^{3}-10^{7} \mathrm{CFU} / \mathrm{g}$
The plate counts of Bacillus licheniformis bacteria in this study gave viable population in order of $4.4 \times 10^{4}-1.66 \times 10^{7} \mathrm{CFU} / \mathrm{g}$.

\section{Conclusion}

B. licheniformishave the ability to survive under harsh industrial conditions and the enzymes produced by them have now replaced several organic and inorganic chemical processes. Bacterial isolates are currently being used for the production of different products on large scale as compared to fungi.

The study focused on anaerobic and aerobic growth of Bacillus licheniformis bacteria indigenous to gasoline contaminated soil. This study show that Bacillus licheniformis bacteria indigenous to gasoline contaminated soil utilized xylene, benzene and ethylene substrate. This study also shows that Bacillus licheniformis bacteria can be use for bioremediation of aromatic compounds contaminated soil such as benzene and xylene [18]. [8]. 


\section{Acknowledgements}

The authors are grateful to Federal Institute of Industrial Research Oshodi, Lagos, Nigeria for permission to use their Microbiology laboratory and equipments for the analysis.

\section{References}

[1] Abbas. A. O. Barack. W. (2005) Polycyclic aromatic hydrocarbons in Niger Delta soil: contamination sources and profiles, International Journal Environmental Science and Technology, 2: 343-352.

[2] Adekunle AA, Adebambo OA (2007). Petroleum hydrocarbon utilization by fungi isolated fromDetariumsenegalense(J. F Gmelin) seeds. Journal of American Science, 3(1): 69-76.

[3] Agarry S. E. C. N. Owabor, and Yusuf R. O. (2012) Studies on biodegradation of kerosene in soil under different bioremediation strategies. Bioremediation Journal, $14: 135-141$

[4] Amund OO, Nwokoye N. (1993). Hydrocarbon potentials of yeast isolates from a polluted Lagoon. Journal of Scientific Research and Development. 1:65-68

[5] Carla, P. (2012). Physiological characterization of a Bacillus licheniformis strain in chemostatcultivations. Department of Chemical Engineering, Lund University, Sweden.

[6] Cicek SS, Khom S, Taferner B, Hering S, and Stuppner H. (2010). Bioactivity-guided isolation of GABA(A) receptor modulating constituents from the rhizomes of Actaearacemosa. J Nat Prod 73:2024-2028.

[7] Chukwuma, M. (2012). Crude oil pollution raises cancer risk among Nigerians.

(http://africancancercenter.com/crudeoil.htm). Retrieved 02-03-2012. pp. 1-3

[8] Cutright J. T. Erdem Z. Partovinia A. (2015) Growth and DDT degradation capabilities of aerobic bacterium Alcaligeneseutrophus A5, Corynebacterium sp. and a consortium of the two species. Source Journal Bioremediation, $1: 1-11$.

[9] Das N, Chandran P. (2011) Microbial degradation of petroleum hydrocarbon contaminants: an overview. Biotechnology Research International, Vol. 2011, Article ID 941810, 13 pages.

[10] Ijah, U. J. J and Antai, S. P. (2005). Changes in physicochemical properties and fungal population after application of crude oil to soil. Journal of Environmental Sciences, 9:64-72.
[11] Li H, YH Liu, N Luo, XY Zhang, TG Luan and JM Hu.(2006). Biodegradation of benzene and its derivatives by a psychrotolerant and moderately haloalkaliphilicPlanococcus sp. Strain ZD22. Research Microbiology, 157: 629-636.

[12] Maria G, Asma A, Afsheen A, Rashida R. Z, Nadir N. S, Shah A. Q. (2013). Isolation and characterization of different strains of Bacillus licheniformis for the production of commercially significant enzymes. Pak. Journal. Pharmaceutical Science, Vol. 26 (4):691-697.

[13] Mathava K, Ligy P. (2006)Endosulfan Mineralization by Bacterial isolates and Possible Degradation Pathway Identification: Bioremediation Journal, 10: 179-190.

[14] Minai-Tehrani, D. and Herfatnanesh, A. (2007). Bioremediation of aliphatic and aromatic fractions of heavy crude oilcontaminated soil: A pilot study. Journal of Bioremediation, 11: 71 - 76 .

[15] Minai-Tehrani D., Minoui S., Herfatmanesh A. (2009) B. Environ. Contam. Tox.,82(2), 179-184.

[16] Nilanjana Das and PreethyChandran, (2011). Microbial degradation of petroleum hydrocarbon contaminants: An overview. Biotechnology Research International, (2011):941810. PMC. Web.11 Oct. 2017.

[17] Novick, A. (1955). Growth of bacteria Annual Review of Microbiology, 9: 97-110.

[18] Odola O. I, Owabor C. N, Odola M. N. (2017). Anaerobic and aerobic growth of Alcaligenes eutrophus in gasoline contaminated soil of Federal Institute of Industrial Research Oshodi (FIIRO), Lagos, Nigeria. Microbiology Research International, 5(4):51-54.

[19] Saroj, A. and Keerti, D.(2013). Isolation and characterization of hydrocarbon degrading microorganisms from petroleum oil contaminated soil sites. Bull. Environ. Science research. 2 (4): $5-10$.

[20] Asad Umar, Patricia J. Gearhart. (1995). Reciprocal homologous recombination in or near antibody VDJ genes. European Journal of Immunology, 25:8.

[21] Osuji, L. C. and Adesiyan, S. O. (2005). The Isiokpo oil-pipeline leakage: Total organic carbon/organic matter contents of affected soils. Chem. Biodiv, 2: 1079-1085.

[22] Sumit K. (2011) Bioremediation of chlorpyrifos by bacteria isolated from the cultivated soils. International Journal of Pharmaceutical and Biological Sciences, 2(3): 359-366. 